\title{
Accused of being a separatist
}

\author{
Dolf Faidiban
}

I was once accused of being a member of the Organisasi Papua Merdeka (OPM, Free Papua Movement). The military resort commander (Danrem) of Manokwari, Colonel Toha said: 'Faidiban is OPM, so arrest him!' At the time I held the position of head of the political division in the kabupaten (regency or district) of Manokwari. Actually, the position had been granted to Mr. Saulus, while I had been assigned as head of the administrative division. However, I asked the bupati (regent or district head), who was a Batak, to place me in the Political Division and Mr. Saulus in the Administrative Division. The proposal was approved.

A job in the political division, in the eyes of Papuans, was very dangerous because it was related to intelligence. Working in this division sometimes made a person get blinded by money, to the point that it got the better of his conscience. I then took bold action. Anyone who would sell out ignorant people who knew nothing at all, and the likes, in order to gain a position or money, could look elsewhere for that. At the time when Indonesia had just come in to the country, there were many Papuans who wanted to ingratiate themselves in order to obtain positions. People who were not OPM were said to be OPM. People who had said nothing were reported and eventually put in detention without a fair trial. I was trying to do away with all that.

Eventually it came to a head. Even I got hit. The story was, there were some people from the interior - from Awom. They were led by Jakobus Asari. They came to tell me that on 17 August they were going to attack Manokwari city. So it was around the fourth that they came to meet with me. I said: 'Don't! Don't do it! If you attack Manokwari, later you can hide behind trees, leaves, rocks, earth, hills, and so on. But the people, the people in Manokwari, the Papuans in Manokwari, will be wildly cleaned out. So, don't you do a thing. That's it, finished!' 
Apparently, however, there were people who wanted to curry favours, wanted to secure positions by selling other people out. I had a driver, who was also my own uncle, Rumere; maybe because he wanted to secure a position, he decided to report me. So, the bupati, who was my protector, could not do anything, because there was an eye witness, uncle Rumere! The one who reported me was given the position of camat in Merdei, where, when it was still the Dutch era, I had once been the district head. I was held for three months in police detention. But that was alright.

In detention I gained great experience. I too felt how hard it was for people in prison and how our hearts were set against them. Coming out of detention, that same day I was ordered to go directly to Hollandia. A position had been prepared and was waiting for me there. After I got there, I immediately became the head of the Education Division, and served concurrently for much longer in the province under Drs. Karsono, head of the Bureau of Government Administration.

\section{A TEN-GUILDER ALLOWANCE}

I was a graduate of Opleidingsschool voor Inheemse Bestuursambtenaren (OSIBA, School for Indigenous Administrators). There were two ways to continue studies at OSIBA, first, by graduating from Primaire Middelbare School (PMS, junior high school), or second, from Jongens Vervolgschool (JVVS, follow-up school for boys). ${ }^{1}$ PMS graduates were given the chance to follow studies at OSIBA for three years: two years of theory and one year of practice. Whereas those who came out of JVVS had to study for a longer time, five years in all: two years of theory, followed by one year of practice, then a return for a final two years before taking the final exams to then go into the community.

I myself was educated at OSIBA for five years, since I was a graduate of JVVS Korido in Biak. The director at that time was Mr. van Kempen. My education at OSIBA was financed by the government of Netherlands New Guinea. So there were no fees from parents for any of it. Accommodations in the dormitories were covered by the government.

JVVS was a 'follow up' (vervolg) school after village primary school (dorpschool). Its function was to upgrade the students' village primary education and prepare them to access the Anglo Saxon (Pacific) high school educational system. From JVVS they went onto PMS as junior high school, and from PMS to OSIBA, which was a mixture of senior high school and administrative training. 
We received help from our parents, but that was for things that had nothing to do with education.

At the Bestuursschool there was government aid. In the first year of studies we received an allowance of ten guilders each month. Later, in the second year, it was 20, and in the third year, 30. In the fourth year, because it was practice, we were given even more. If I am not mistaken, during practice in Sorong we were given 150 guilders, which was also the basic starting salary for a candidaat bestuurs-assistent (CBA, assistant administrator candidate).

When the assistant-resident asked me to work at night, he gave me a stipend too. So when I returned to OSIBA I brought back lots of money! The OSIBA curriculum did not distinguish between the PMS and JVVS graduates. The curriculum was the same. The OSIBA curriculum in 1953-54 consisted of these subjects: 1. Nederlands (Dutch language), 2. Rekenkunde (arithmetic), 3. Beginselen van Nederlands strafrecht (principles of Dutch criminal law), 4. Beginselen van staatsinrichting (principles of the constitution), 5. Staathuishoudkunde (political economy ), 6. Land-en volkenkunde (ethnology), 7. Hygiëne en verbandleer (hygiene and first aid), 8. Politievakken (police studies), 9. Administratie (administration), and 10. Lichamelijke opvoeding (gymnastics). That was the curriculum for the first stage, before practice. After practice, our curriculum in 1957-1958 was: 1. Beginselen van het strafrecht, 2. Administratie, 3. Staatsrecht (constitutional law) 4. Staathuishoudkunde, 5. Politievakken, 6. Land-en volkenkunde (which sometimes was related to ethnology), 7. Hygiëne en verbandleer, 8. Nederlands, 9. Rekenen (arithmetic), 10. Lichamelijke opvoeding.

The topics that remained applicable in our government duties were staatsinrichting or staatsrecht (constitutional law) and land- en volkenkunde (ethnology). In fact they were number one. The teacher for these subjects was Mr. Raphael den Haan. He made me so interested in going there. Even if I felt a little sick, if Den Haan was coming to teach, I forced myself to go in, even if the teacher knew I was sick. I was fascinated by his way of teaching, his style, all of it was interesting! Staathuishoudkunde, which had to do with economics, I applied in developing communities to do farming and household reforms in communities that were still very simple. 


\section{HALF OF US FAIL}

In the first year class there were 24 of us from all over Netherlands New Guinea. After entering the practice year following the exams, only 12 students made it into practice. So, 50 percent succeeded! The advance selection, based on various aspects, really was good enough to establish which people should go into the field. They also had to be role models! Their behaviour and capacities to think had to be like Mr. den Haan's, so that they could do more for society. I was most pleased by his way of teaching because that way we learned to find out about the situation in a given community and how to make it orderly, in terms of the government's vision. Mr. den Haan taught staatsrecht, but more often his themes carried over to ethnology. Perhaps because he had travelled a lot in the interior, he knew this was right. I was sympathetic to the man, and to the methods and subjects of his lessons. And maybe it was because of this that I had high grades, often a nine! I did not see Mr. den Haan outside of OSIBA, since all 12 students who had passed were placed to practice across Netherlands New Guinea. The selection was tougher that first year. An OSIBA graduate, whether he had gone through three years or five years, was appointed to be a candidaat bestuurs-assistent (CBA, assistant administrator candidate), namely, the initial rank for any abituriënt (prospective student) of OSIBA. He could be placed at an HPB's office, a district office, a resident's office, or another government office. As often happened, when an HPB or resident requested it, he was placed at the Dienst van Binnenlandse Zaken (Department of Home Affairs). Indeed, everything was arranged to meet the needs of the Resident for his area, and so on.

Becoming a bestuursambtenaar (government official) who was independent depended on the job skills of each person. Often, there were some who were a bit slow, but there were also some who quickly rose in rank or were promoted to become the district head or districthoofd. Perhaps because my HPB, Capetti, was good, or perhaps because he liked me, he was often angry, so I tried to not get angry. I tried to attract his sympathy, so in three years' and five months' time I was promoted. Usually it was only after five or six years that you got promoted. Then, after a few months passed, I was promoted again. Both Capetti, and later, the aspirant-controleur (incoming prospective controller), Mazairac, were very good, especially Mazairac. Because he was aspirant-controleur, and still 
young, we often hung out with each other outside of office hours. He also encouraged me, maybe because at the time I was the youngest bestuursassistent (assistant administrator) under Mr. Capetti in Teminabuan.

In three years and five months I was promoted from candidaat-bestuursassistent to bestuurs-assistent, and in exactly four years I was holding the position of districtshoofd of Teminabuan. One month later I was serving as an onderafdelingschef (sub-division administrative head) in Steenkool (Bintuni). Apparently, the Dutch government at that time already saw that no matter what it did, Netherlands New-Guinea was going to be handed over to Indonesia through the UN. So they had already put papuanisering (papuanization) into operation at the time. Seven sons of Papua were for the first time appointed as sub-division heads, including me, the youngest of all, since I had only been working for four years after leaving the school for administrators.

To prepare to serve as a sub-division head I was summoned to Manokwari by Resident van Bodegom. At the time his wife had gone home to the Netherlands because she was sick, and I stayed at their house, taking part in his life from home to office. Presumably, this raised the suspicions of my friends there: why had I came from Teminabuan to live in the house (of the resident) and why could I only go out with 'bapak'? He had his ways--which I complied with properly, both in and out of the office--certain ways I had to behave. When that was done I was sent back to Teminabuan. Following that came the decision that I should go to Steenkool.

The basic problem in positioning oneself as a public servant lay in knowing the people around me: were they primitive people, or people with education, farmers, fishers, teachers, health officers, doctors, government officials, controllers or HPBs, village chiefs, or poor people? All of those were environmental factors that influenced the government administration and the leadership psychology of a tuan bestir or administrator. As a consequence of such varied environmental factors, I had to learn and understand the relationships and linkages and influences of the system and subsystems among human beings, the people, the officials, with each other, and the environmental influences.

These things were really very interesting for me personally, not just as a government official, but also in terms of how I saw and got to know people, and what approaches should be applied. The resulting understanding of how things were among humans, between the people, the 
administration and the environment, I applied psycho-sociologically in performing my administrative duties and services in the community. I think this was important, because at the time when I went into service, I had just turned 18, so there was no need to collide with the others. Especially with people who were still poor and isolated or were at the 'prismatic society'2 stage. This approach seemed to succeed in Ayamaru, Aitinyo, Aifat, and Teminabuan, and eventually, in Steenkool.

\section{REFUSING THE RESIDENT'S CALL}

I could explain the Dutch perspective and approach to Papuans based on my background. In Teminabuan I worked as a deputy to the district head on the construction of the Teminabuan-Waigo-Ayamaru road, which was 20 kilometres long and was carried out using manpower and dynamite in several locations. The purpose was to support the development of chocolate, coffee, and rubber plantations. Unfortunately, after the road was finished, the implementation of the programme could not take place due to the change of government.

During the inauguration of the road from Teminabuan to Ayamaru, the older Papuan, Ambonese, Manadonese, and other administrators in charge of the construction of the road were ordered to stand at the doors, while members of Nieuw-Guinea Raad (New Guinea Council) and the Dutch Government and others, including me, were invited to eat inside. In the words of HPB Gonsalvez, the older administrators were to ensure that the public did not come in and disturb us.

I told Mr. van Bos that I did not accept this, but he just remained silent. So I went outside, to stand beside the older administrators, too. Mr. Gonsalvez kept telling Mr. Wanma: 'Please call Dolf to come inside.' I did not want to come inside, I stayed outside with the men. I said I did not want to come in, because I did not want to show that I was angry. I persisted in showing my sympathies, since the public was out here, while the respectable people were inside. So I said: 'Tell Mr. HPB to just let me keep watch with these men, especially since I'm young, so they're in sympathy with me.'

$2 \quad$ This term refers to the ideas of Riggs 1964. 
But apparently Resident van Bodegom was looking for me. He ordered Gonsalvez to call me inside. I said to Gonsalvez: 'Sir, this policy measure of yours is wrong, it's mistaken. These older administrators have devoted themselves much more, with all of their strength, to this road. I came here only a year ago, and you, Mr. Gonsalvez, only eight months ago. Neither of us began undertaking anything, it was they who began it! I have to stand guard with my young friends, so the older ones do not feel excluded.' There really were some things we thought we could tell him (Gonsalvez), because he too was only human. That perhaps he was mistaken, as long as it was conveyed politely, so Mr. Gonsalvez would accept it. At first he did not want to accept it, he was a little strained with me. I said: 'Mr. Gonsalvez, go back in there,' but he pressed on: 'You have to go in, it's the resident who made the request.' I said no, I was sure that Mr. Resident would not force me to eat.

\section{THE HISTORY OF THE ESTABLISHMENT OF THE DISTRICTS}

I will try to explain a bit about the time the districts in Netherlands New Guinea came to be established. In the first stage, one government post was established in Manokwari, starting from 1936. It was headed by an assistent-resident, Van Eechoud. The Papuan people still lived in isolated groups and often fought each other. It was impossible for the government to implement development. Initial contacts were focused on ways to bring together people who lived in scattered locations into one large community, in villages on the north coast of Papua and in the southern part of Papua. What the government did at the time, aside from reconciliation, was mainly to help communities affected by malaria, which was such a dangerous disease and had already taken so many victims that the population of Papua was not increasing much. They got through this phase alright, although at the cost of many obstacles and sacrifices.

The second phase involved the opening of government posts in several different places. Fakfak became the headquarters for the assistentresident. Then there was a post in Merauke on the south coast, followed by posts on the north coast in Hollandia, Serui, Biak, and Sorong, and in a number of other areas. The Dutch administration in Papua, which still had assistant-residence status, was still under the control of the resident in Ambon. The difficulty of transportation between Ambon and the 
assistant-residence in Manokwari was the main obstacle to an effective government administration. Under those conditions it was not possible to undertake intensive development, even though education began to be implemented in most areas of northern Papua and in a few areas in the southern part of West Papua.

It was only in the third phase that the government administration began to be developed, following the end of the Pacific War, and this was marked by the opening of government posts in various other areas, both on the coast and in the interior. In brief, it was only after the Pacific War, that is, starting in 1945, that any significant development was carried out for the people of Papua.

The Dutch approach that the nation of Papua holds in reproach, especially the younger generations in the years 1958 to '69, was the delay in the decolonization of West Papua through the United Nations, in preparation for Papuan independence, through which Papua would be associated with the Netherlands in friendship, for welfare and prosperity.

\section{EXPERIENCES WITH DUTCH ADMINISTRATORS}

Together with friends from the administrative school such as Mr. Bos and Mr. van der Molen, I was placed in Dok V. We got along together and were as familiar as if there were no HPB. After leaving the office we would have drinks first, before each of us went home. If someone wanted to go swimming, he would call up the others for us to all go swimming together. The closeness let us get to know each other, perhaps there were two or three of them, including Mazairac, as well. Because of those feelings, what they knew of me, they thought other Papuans were also like that. It was the same in Teminabuan and Ayamaru, even in Steenkool. In Steenkool I was new, and the atmosphere there was rather different than in Teminabuan or Ayamaru.

The ways of interacting there, say, with the Papuan elites that the administrators knew, they also applied with the communities. When we went on field tours, we slept together with the community. When they came over in the evenings, they were inquisitive because they were still young. Maybe this one wanted to deepen his knowledge of sociology, another, his knowledge of some other field. After we explained our mission in coming to the village and then everyone would go look for the 
elders, to gather materials for whatever he was working on (an essay or thesis). Eventually, the relationships improved, and we always provided tea, coffee, or cigarettes for them.

Sometimes, when it was getting late, Mr. Bos would say something like: 'Oh, you sleep here, we'll sleep together in the camp.' So it was! Just as in Irian, some people had brains while others could be extremely irritating, so also the characters of the Dutch administrators varied. But we in the division of West Nieuw-Guinea under resident Van Bodegom rarely had any difficulties. The young ones, whether Papuan or Dutch, were often gathered together by Resident Van Bodegom. That was his approach to create an atmosphere in which his territory could run well, or perhaps, to get a letter of good conduct from the Dutch queen, or maybe from the governor? Since I was a candidaat bestuurs-assistent and (at the same time) on the technical staff in the area of administration, my working relationship with the onderafdelingschef $(\mathrm{HPB})$ was very close. $\mathrm{He}$ was the administrative leader in the region, so as technical staff, we had to assist him well. In carrying out his duties, the HPB at all times required information about the state of society, in terms of various aspects of life, in the areas of government, politics, and security, the state of the villages, people's economic issues, education, health, and other aspects of society.

In trying to get familiar with the problems of government, politics, and so on, the HPB could instruct the CBAs or young administrators to conduct a survey in the field. This could be done through a special survey or through sporadic trips to some of the villages in his territory. Sporadic, meaning several times a month and in several different places so the data we gathered would be representative. Our approximations could come close to being true for the whole region.

In 1958, when I was in Teminabuan, the HPB, for example, would ask: 'I need this, let's see if the Wersar people have enough land for us to clear to plant coconuts for them. And if we were to clear it, what weeds might we need to eradicate; and from a cultural point of view, are they interested in coconuts or not? Perhaps there could be other crops?' Yes, that's what it was like! Then later there would be surveys in a few more places, so we could order seeds and know the number of villages and number of people we needed. Then we were given assignments: 'You try to finish that job and you may pick anyone you want to help you, and after two or three weeks, please report on it in writing.' For example, in the case of agathis trees, they were tapped from Wersar to Konda, 
and from Yahadian, from Inanwatan, and from the southern part of Aitinjo. The resin was tapped for a cooperative called Koperasi Sena Taji Weta Nagin Brat (WNB) in Teminabuan. At the time (1958) agathis production was actually already being done by the Forestry Department. The results of observations or fact finding in the field were reported in a special report or toerneeverslag (patrol report) that was then intensively studied by the HPB. Following from the results of the HPB's assessment a staff meeting was held, consisting of government administrators, both Dutch and Papuan and people of other ethnic groups, along with the related agencies, such as health or education. Or the agrarian agency, if there was a connection to land issues: if we wanted to plant certain specific crops, would clashes not happen between tribes, or between one village and another because of customary land rights issues (hak ulayat)? All of that had to be discussed beforehand. Or later, meetings with the Agriculture Department or another agency were also required to address outstanding problems and resolve them.

On such occasions, the CBA could play a dominant role in making pertinent and reasoned recommendations on the problems discussed. But they had to get support from the meeting, especially from the HPB. The CBA who conducted the survey had to directly see and be familiar with the field, because those assembled would listen to his recommendations more than those of all the others, who only took part in giving their reactions.

But at certain times, when the recommendations just continued to be well received, the HPB became suspicious. He wondered, why is it that, when Faidiban speaks, he is always supported by Van der Molen and Wanma? All of his reports continue to be supported! Is it actually doorgestoken kaart (a put-up job)? Sometimes the HPB really said that; he was not convinced. I said: 'Let's go into the field together so you can see for yourself, sir'. Of course there was cooperation. This meant that all of us under him endeavoured to keep everything running well.

While in Teminabuan or Ayamaru I never heard of a report from the community about an administrator who was misbehaving or not performing his job well. A CBA did not just take orders all the time, he could also get input from the HPB, who at the same time suggested solutions to resolve things. The young CBAs who were quickly promoted in rank or structural position were those who were proactive in helping the regional leader or sub-division head to overcome various administrative, developmental, and social problems in the sub-division. 
Beyond the formal or official employment relationships there were very intimate informal relationships among the administrators, with other Dutch people, and with Papuans and Papuan tuan bestir. I myself spent almost every Saturday night relaxing with my Dutch administrator friends as well as with the aspirant-controleur, Mr. Mazairac. We relaxed, drank, ate, and sang. Also, after ending work at 15:00 in the afternoon, if any of us had extra pocket money, the others would be invited to have a few glasses of beer before returning to our own homes.

Mr. Mazairac, Mr. Bos, Mr. van der Molen and I always had close ties. We were all actually bachelors. Except Mr. Mazairac, who had a family, but was still a young man. On every first Saturday night of the month a dance party was held at the police canteen for people from all ethnic groups - Dutch, Papuan, Chinese, and Indonesian, such as Ambonese, Manadonese, Sangir Talaud, and others based in Teminabuan.

At the time in Teminabuan there were no 'BBM' - that is, no Bugis, Butonese, or Makassarese. There was only one person, who ran an alligator skin enterprise. His name was Saleha, he was a good person. At the dance parties, those who were already married stuck with their wives, those who were single, with the Dutch and Papuan nurses, or the Dutch, Papuan, and Indonesian teachers. Relations between the Dutch and Papuan women were also good, although they did not mingle that often, not like Dutch and Papuan men did. They exchanged birthday gifts, which could be sent or delivered directly to the birthday parties they organized, whether for children from Papuan, Dutch, or other ethnic groups.

I really did not see any discrimination, although differences did appear to exist in everyday relationships with ordinary people. That is understandable because of psychological factors. We could not force village people, who were still so simple, to interact on close terms with the ladies or gentlemen around the HPB and others. Acknowledged or not, under any conditions there are always differences. Because while one may want to embrace others, those one wants to embrace may feel insecure. The same was also true with me; as a Papuan, there was also some distance. I wanted to immerse myself among ordinary people because I wanted to know more, because the Biak people might have social problems that differed from those of the people of Teminabuan. But they always called me 'Mr.'. Actually, it was fine to be called 'Mr.', but over time it became 
an indication that there was still distance between one group and another. While there were striking differences related to racial differences those who were white-skinned, blond-haired, or brown-eyed - those were gifts from God, to be grateful for and not for debate. That was the reality.

When I reflect on it now, if I compare things with today, the distance now is really great between the people and the government officials who have the top functions. When they come it seems as if they really love the people, but it is only on the outside, not something that comes from their consciences, it is more contrived. For example, when I was still active in Dok II, there was a debate about that. I said that we, namely the people of Indonesia, were the most hypocritical people in the world. We must not blame others. Look first (within oneself). With our mouths we say kind words, but in our hearts we are like vipers. Whereas it seemed the Dutch at the time were more spontaneously open and honest, while their attitude maybe also had to do with religion. If there was this hypocrisy, we would really quickly come to know it.

\section{BEATEN BY THE RESIDENT}

When I served as a CBA in Teminabuan I had very good working relations with Controleur F.J.M. Capetti, Aspirant-controleur Mazairac and Controleurs Mr. R.A. Gonsalvez, drs. E.A. Polansky, and Van Bodegom, and finally, Resident van der Veen. Van der Veen once beat me because of something I did. When I was staying at his home, I came home late, so he beat me. He beat me with a rod, but he only beat people he cared about. He told me to lie on the table, then he struck me on the rear with the rod. But I knew he was affectionate, because if it were someone he did not know, he would not strike the person. Apparently everyone knew that if someone who was close to Van der Veen made a slight mistake, he got beaten. So we felt we were treated as children.

When Mr. van Bodegom returned to the Netherlands, Van der Veen came from Hollandia to replace him. It happened that I had already been released from my position as sub-division head in Bintuni and had come to Manokwari because I had been summoned by Mr. Soedjarwo Tjondronegoro to follow studies at the Akademi Pemerintahan Dalam Negeri (APDN, Academy of Domestic Government). When I came to live there he said: 'Do not show bad character.' What he meant was to 
demonstrate the good character we had been taught, even after we were separated from the Netherlands. 'But if you come home drunk, you could be beaten!' said Mr. van der Veen. Just imagine, a former sub-division head being beaten by a resident! But I did not feel any hatred or contempt.

There were stories about Mr. Gonsalvez in the Baliem Valley, and also, Mr. Raphael den Haan in Enarotali. Indeed I had studied their reports a lot, and from there I sometimes drew things that were relevant to the process of administration. Raphael den Haan himself, when he came, had to reconcile people who were fighting. Because he was daring, he intervened even when he was threatened by a spear, or whatever else, and he would keep advancing; because he was good-hearted, he could overpower people. Because he came to reconcile people for the good. Ah, that was a principle I used, too. And not only me; many of my friends in the government used that method.

As for Gonsalvez, he acted so tough, he even became a hero to the village that lost. It was he who helped them kill, he who shot. Yet later he received the Dutch Order of Knighthood for his deeds. If it were me, I would convict the villagers, but at the same time educate them and adjust the views of justice found in the community. If village A kills two people from village $\mathrm{B}$, then village $\mathrm{B}$ will try to retaliate by taking an equal number of victims. If we punished only village $B$, to them that would be unjust.

Gonsalvez really was threatened by Papuans at that time. I asked, why was it that he was not punished? Or dismissed? Instead, he was given the Order of Knighthood. So, my reading was: $\mathrm{Oh}$, so that is how it is! Now, if that is the case, actually he did not have to, but if he had let himself be killed, then he would also have been just! Because the victims would be equal. And according to the local community, that would only be fair. I think it depends what point of view we see the problem from. What is considered fair in one society may not necessarily be fair in another. So, from which angle do we see such a raid between villages, and based on which deeds, which facts of who kills, and why, do we judge?

\section{THE CLOSING OF THE OIL FIELDS}

Bintuni, which was then called Steenkool, is a mining region, at that time involving petroleum. So the community there was already used 
to money. Suddenly there was a change in government. The Dutch government exited and was replaced by the United Nations Temporary Executive Authority (UNTEA). The oil fields were no longer operating and got closed down. Well closed down, so there would be no leaks and so on. The livelihoods of the people there shifted to other enterprises. As it happened, the people in Bintuni lived on a coast that was rich in fish, shrimp, and so forth. It was even rich in sago; one of the 'sago barns' for the future of Irian Jaya.

But then I heard that the natural gas company coming into the area was deliberately planning to damage it. That was a problem. Since I had worked there before, I asked for the files I had compiled to study. I also asked the first vice-governor to review them, lest the sago owned by the community get burned by the company. Companies could come in. That was no problem, if it was really for investment and for regional development. But it should not be allowed to go as far as destroying the food provided to the community by nature. They needed sago on occasions when economic crises like the current one happened. In fact it was also a living environment, a living habitat for a variety of natural animals such as fish and shrimp. Really rich!

Now the community there was already advanced. At the time there was a only a missionary post. Then I established a government post, Merdei district, which was located between Manokwari and Bintuni. The one who served as district head there was Mr. Eli Major. Today he is in Sorong, he has retired. Eli Major was my senior. Back then I said to him: 'Pak Eli Major, for the time being, you serve as the district head here, to foster regional development.' He served for three months there. After we brought in a young district head, he returned to Bintuni.

Merdei became a district, now a kecamatan (sub-district). It was also an area we considered important as a government post for development. So, for the economy and for whatever else, it could serve as a 'growth pool' in the interior. And today it is great there. If you go there on foot, it takes two days to get there. At that time it took me one day! Now it would probably take me a week. When Mr. Major and I walked there, the distance between us could be three to four kilometres. I said to a policeman: 'Give your weapon to someone else, just use a pistol and follow me, so we can walk fast! This was because we were curious, we wanted to know all about the interior and its peoples. So it was that curiosity that 
motivated us. Sometimes, curiosity is not a good thing, but it seemed to be good for that!

\section{EXPERIENCE DURING THE UNTEA PERIOD}

Approaching the time when the UNTEA came in, I was transferred from Teminabuan to Bintuni. In Bintuni I replaced Sub-division Head Mr. Roemer, who was going home to the Netherlands due to the change of power from the Dutch to UNTEA. I was assigned the position of $\mathrm{HPB}$. As the HPB, or the area commissioner $(\mathrm{AC})$ in the district head in Teminabuan.

My responsibilities included running the administration, community development, organizing development and education, the economy, public health and order. This was a heavy load for a young HPB only 20 years old. It was truly an honour but also a burden, a duty, and at the same time, a responsibility to my people, who inhabited a fairly broad region bounded by Fakfak sub-division, and bordering Sorong sub-division to the west and Manokwari sub-division to the north.

In the field of law, as the single judge, or alleensprekende rechter, I had to enforce the law through a court of law and aim to act as fairly as possible based on the codified laws or Wetboek van Strafrecht (penal code) for citizens who really had an awareness of modern law. For the people of the interior (who were primitive) I applied adat law. The expedience of justice according to the habits of primitive society: by following religious norms and raising their humanitarian conscience not to kill and commit other serious offenses.

At the beginning I had to accept strong rebukes from the UNTEA resident in Manokwari and the UNTEA administrator in Hollandia, but later they were able to understand the application of the punishments I gave to the rural people. What mattered here was not an issue of how heavy or light the punishment was, nor a judiciary concern according to their customs or adat, but rather it was about applying sanctions to them so they would realize that taking another person's life was a sin.

In the field of administration I sped up the promotion of the Merdei post into a district and appointed my senior, brother Eliezer Major, as a District Head with the approval of the UNTEA Resident and Administrator. The recruitment of prospective honorary employees in 
the office of the HPB was also accelerated. Those who had already been recruited by Mr. Roemer were appointed as civil servants. At that time, this was not too difficult, because in Jayapura there were still a lot of Europeans who probably realized that what was going to happen in the future could be different from what they expected, so they agreed with all of our proposals. There were already many honorary employees who could be appointed as civil servants. I tried to do this so that when I left, no one would feel they had suffered losses or had been overlooked.

Papuans as well as non-Papuans, such as the Chinese, Manadonese, and Ambonese, were all prepared to obey the new government, by working and doing their best. The Ambonese worked at it just like the Papuans, but harder. Some, at the time, thought they were a bit too extreme. I said: 'you mustn't make anything of this, the main thing is, don't let it get to the point that when I get out of here there's a rebellion, because then I would be the one they'd think had dropped the bomb.'

PEOPLE START TO WORRY

The entry of the UNTEA as a transitional government to replace the Dutch government was significant in bringing about certain impacts, such as psychological-political effects, among others. Papuan people began to feel as if something disturbing was going on. They doubted the ability of the UNTEA Government and the UN to guarantee political rights to freedom or to defend the independence of the Nation of Papua, which had already been marked by the raising of the Morning Star flag while at the same time humming the song, Hai tanahku Papua (My land is Papua) to the whole world. The doubts were mainly focused on the New York Agreement, especially the chapter on the implementation of the right to determine our own fates. Would it truly be applied fairly and honestly, one man one vote? Or would it be reengineered in the form of democracy that commonly occurred in Indonesia, turned into musyawarah untuk mufakat (deliberation to reach a consensus), which was often won by the ones who played a stronger role, or whose arguments won by a majority, while those in the minority were always parties that were unrepresented.

The things that Papuans began then to have doubts about later came to pass. That reality was tangible, and even up to now, still exists, the 
deviations made by the Government of Indonesia, but never annulled either by the UN, the United States, or the Netherlands. Here, it seemed, was a feat of international political engineering that was followed by the United States, especially President John F. Kennedy, and Indonesia, and was forced upon the Dutch. Due to fears of an imminent military clash between the Eastern Bloc (the Soviet Union) on one side, and Indonesia and the Western Bloc or NATO, which was, of course, on the side of the Netherlands as an ally within NATO.

This I found out - I was working at that time - and night after night I would often turn on the radio to follow political analyses from the Netherlands, Australia as well as the BBC in London. Once there was an analyst discussing the crescent area and the fact that Indonesia happened to be located in the outer crescent area, so that if the Soviet Union could take control of it, this would mean that they would also control the Pacific Ocean, and the United States would be under threat.

\section{AN EPIDEMIC OF CORRUPTION BEGINS}

Another effect of the entry of the UN had to do with the issue of language. Papuans, especially those involved in civil administration, had to learn English in order to communicate with the UN officials who took over the key positions left vacant by the Dutch officials. Clumsiness and impasses in the communications of the administration occurred; likewise, there were lags in many administrative matters that needed to be fully resolved. Very few of the Papuan officials could anticipate the deadlocks that occurred in the administrative channels of government and development.

In connection with the language problem, Indonesian officials emerged to act as mediators in the administration of government and development. The Indonesian language was officially made the language of mediation. This opportunity was used to achieve the political goals of Indonesia. Here and there the facts were twisted, for instance, the fact was that Papuans rejected the system of democracy by deliberative consensus, but the UN officials or non-Indonesians were told that the Papuan people agreed to it and rejected the one man one vote system. That is the danger of language. The people were deceived, threatened 
and treated inhumanely, especially to carry out the Act of Free Choice, which referred to the New York Agreement.

Another problem had to do with the turnover in government positions. Many Papuan officials were replaced by Indonesian officials based on the rationale that they were attending courses, inside or outside of the country. Corruption was appearing everywhere, something that, during the time of the Dutch, had almost never been found carried to other provinces in Indonesia. Papuans could not reproach it because they would be accused of being separatists. They really could not challenge it. If a person was like me, a government official, among fellow officers, he could do so. I could say openly: 'We do not know that culture here. It's a culture you have brought here.' I could talk like that, but an ordinary person, such as a teacher, would be reported to the police or the military.

As I mentioned earlier, while the UNTEA was still here, Indonesia had actually already come as well. They were already buzzing about, especially those who were acting on behalf of the diplomatic corps, they were already there in the UNTEA period. Perhaps without the knowledge of the Dutch, the United States and the UN, there were already a lot of them here. Many teachers had come, men and women, even more women. There were not really any merchants yet, but people from all the lower echelon agencies or departments were already here. The outside world did not know it, as the Indonesian government very cleverly engineered things so that there were already so many people here who were regarded as the staff of the diplomatic corps staff to assist all the officials and so forth.

\section{SILENGED INSTITUTIONS}

I am sure that the UNTEA also knew it, but it seemed that the UNTEA did not address it, and suppressed the circumstances. This gave rise to a sense of suspicion among Papuans. So, if you have ever heard the expression, 'international political engineering' that was one of its indications. But Papuans could not talk. The members of the Nieuw-Guinea Raad, which had formerly been so clean and able to speak so freely, could do nothing anymore. Essentially, all of the governance institutions that had been developed by the Dutch Government for the Papuans were totally paralyzed. The members of the Nieuw-Guinea Raad existed, but 
they were disfunctional and they were under frequent observation, like Tanggahma. In the UNTEA's view Tanggahma was the most dangerous. Finally, he died in Manokwari after drinking a glass of coffee.

Formerly, with the Dutch, we could quarrel, but then shake hands after it was over, not in a false way with but with a genuine handshake. But with the Indonesians, you could not, they would usually defer. I noticed we did not look each other in the eye, rather they averted their eyes. Sometimes I called this a provincial nature, even though I myself come from a village. In the end, there was a gulf, which I am sure that, until the Lord Jesus returns, we will never be able to escape. I am not the only one who thinks so, many other Papuans do as well.

When we met together with all the Indonesian bapak we left it at that; after the round, everyone back in the confines of their respective boxes, there were no relationships among one another. If we met, everyone was hypocritical; the Papuans too were forced to be hypocritical. Luckily we were able to adapt. Sometimes I say that the reason for hypocrisy among the people of Papua is that they adapted themselves to the culture that came from there. Hypocrisy does not exist in the culture of the Papuans. They cannot respond, perhaps because they feel offended.

\section{LAW ENFORCEMENT DURING THE UNTEA PERIOD}

Perhaps I can give one more example of public administration during the UNTEA times. At the time, murders still took place between one village and another. When this happened, I reported it to Jayapura, then called Hollandia, to the UNTEA administrator, Dr. Djalal Abdoh. He replied: 'It should be punished hard.' But I gave a light sentence. The most serious crimes should have been punished, based on the Wetboek van Strafrecht, by sentences of 15 years, 10 years. But I gave 1.5 years. Those that called for up to five years, I gave only a few months.

I received strong challenges from the UNTEA government, as well as from Manokwari, from Mr. Cameron. By coincidence, he had a master's degree in law. A sentence was meted out by a judge in a court of law in order to develop them. The punishment, for those convicted, was to be locked up or detained. Whereas they were here to be developed or educated (dibina). At the point when the convicts could speak Indonesian well, I returned them to their villages. There they could teach their 
people to live properly, from my point of view. In the opinions of Dr. Abdoh and Mr. Cameron, they should have been severely punished. But after I consulted in Manokwari and was sent to consult in Jayapura with the UNTEA, it turned out that they accepted it, so the sentences were officially approved.

So my view was this: Because justice, according to people in the interior here, was, for example, that if village $A$ was at war with village $B$, both must win equally. That meant: if village A killed two people from village $B$, then village $B$ would also try to kill two people from village $A$. Only this might be called justice. To balance things according to adat. So as long as village $B$ had not yet killed two people from village $A$, the war went on. And other social relationships were certainly affected, as they could not keep gardens far from their village, since village B was always spying. They killed to retaliate for the sake of their sense of justice.

That is what I explained to the UNTEA people. I said that if we killed one person in the city of Sorong or in Manokwari, Biak, Jayapura, Serui, or Fakfak and so on, we would be applying the law in full. But as long as they continued to depend on adat law, and that is what was best and would not give rise to consequences as long as they lived, then it was better for us to follow them, but give them light sentences. And while they were being punished, I sent teachers to educate them, then, from the government's angle. Indeed, a tribal chief who should have been sentenced to 15 years, but I only gave 1.5 years, returned to being the tribal chief in Merdei. So the law we applied in different societies was not the same. These truly were people who still constituted a prismatic society.

But this did not mean that Western law was too harsh, in fact it served as the foundation. Only I adjusted it to the conditions of their laws and customs, their sense of justice. So that too represented the success of the Dutch government at the time, of those who worked in the hinterland areas.

\section{THE KOTEKA AFFAIR}

I also had somewhat conflicting opinions with Panglima (Commander) Acub Zainal about the koteka (penis gourd) problem in Wamena. He held a meeting to raise awareness, and at the same time, get responses and criticisms, input and so on from all of the officials. Only because he was 
a commander, after he spoke, there was no chance anyone would dare raise a hand and give an opinion. So I raised my hand. I thought it would be no problem! I spoke, proposing that 'operation koteka', replacing penis gourds by giving them clothing, was not a matter of clothes, not a matter of shame. It was a matter of culture, something related to the matter of social change.

I proposed that their wearing koteka was the same as our wearing clothes and being in a room in a public building. They did not feel ashamed. Because of that we had to 'elevate' their feelings, so they would feel ashamed. Only when they felt ashamed, would they not wear koteka anymore, would they need clothes. But then, if we gave them clothes there would be many related problems. The commander was telling me to distribute clothing. That was just one set of clothes each. In one day they would get dirty, since their conditions were not yet really conducive to cleanliness. Then they would have to buy soap. Where would the money come from? Their economies would have to be improved first, then their houses. And many of them did not bathe. They would need to know about cleanliness, that the body could only be cleaned with water.

All of this I put forward because he - Acub Zainal - had asked for input. But perhaps he was unhappy. Why was the one talking such a young person like me? Why was it that none of the older ones, the ones with stars, were saying anything? Thus, he banged on the table, he was angry! But Acub Zainal had a way of thinking that was almost the same as a Westerner's.

\section{UNTEA DOESN'T DO MUCH}

The UNTEA period was drawing to an end, and with every incoming ship, a great many people arrived - the Papuans said they had come looking for food. The situation here was beginning to change. Many of the Papuans with positions in the administration were being replaced. They were given the task of going to study in Jakarta or abroad, in Japan. Or to attend police job training, also in Java.

If we compare the results achieved by the UNTEA in West Papua with those achieved by the Dutch in Papua, it may be concluded that UNTEA, in such a brief period, did not do much to develop Papua. 
When I discussed this with Mr. Cameron, he said: 'We are only here as police, to maintain security. We can't do anything, it's not possible to develop anything. We can only bring the information we have heard, so it can later be used, or not. It's up to the UN.'

The UNTEA only came to take over power from the Dutch government in order to transfer that authority to Indonesia. Nor did the UNTEA do much to uphold the fundamental human rights of the people of Papua. Conversely, what the Dutch did, which was to lead the Papuan people from a primitive society into a society aware of its own humanity, was a sacred mission and serious sacrifice.

In the 14 years' time since 1949, the Dutch government had made much progress for the Papuan people; they made the forgotten Papua described by Van Eechoud in the book, Vergeten aarde (Forgotten earth), renowned as a society in the face of the international world. More than that, the Dutch had prepared a basic framework toward an independent Papua, which was marked by the hoisting of the 'Morning Star' flag and the singing of the Hai Tanahku Papua anthem on 1 December 1961.

The UNTEA really did not do a thing. Time wise, we cannot fault them. The only thing that is regrettable is that none of the violations made by the government of Indonesia and people of Indonesia before the surrender of sovereignty were ever reproached, for example, the many people and the army that they brought in, and things like that. Perhaps there was something in writing, but in the mass media outside or inside the country, it seems, no sounds were ever made about that and I never heard any.

\section{STALLED BECAUSE MY FATHER WAS PRO-INDONESIA}

I had been in Steenkool for exactly eight months when Mr. Soedjarwo Tjondronegoro, a senior executive of the UNTEA in Hollandia, came to pick me up, in order for me to attend the APDN in Malang. Actually, if the Dutch had remained one year longer, I would have attended the Rechtsacademie (Law Academy) in Holland, as this is what had been arranged by Mr. Van Bodegom. It is only now that I tell this, because I was not given the chance back then, as my father (Roland Faidiban) was among those who identified themselves as the Golongan Pejuang Indonesia Raya (Fighters for a Greater Indonesia Faction). 
They formed the Partai Indonesia Merdeka (Independent Indonesia Party) on a bridge in Biak that was built but later destroyed by an unexploded bomb.

Due to my father's involvement in pro-Indonesia politics, my expedition to Holland, which was supposed to take place in 1958, did not happen. At the time I prayed, in the hope that the government would not find out, but Dutch security was so thorough, they discovered from a review of my resumé that Roland Faidiban was my father. When I was questioned, I acknowledged he was my father. As it happened, Mr. van der Sluys, Director of OSIBA, called me: 'What about Roland Faidiban from kampung Bosnik, is he your father?' I replied: 'Yes, he's my father.' So I would not be supported by the Dutch government. Never mind, right, it was my fault for having him as a father.

Finally I was sent to the APDN in Malang; but was it to increase my knowledge or to get me out of Papua? Actually both were true. In fact, Resident van Bodegom's records were left with Mr. Cameron, and when Pak Soedarto became the resident in Manokwari - the first Indonesian resident - he asked Mr. Tjondronegoro (who was formerly the Indonesian ambassador to the UN during the negotiations with the Dutch about West Papua) for them. This too was because my father was on the Indonesian side. But a son may not necessarily emulate his father's political tendencies. Actually at that time I often spoke on the radio. The opinions I had were often aired by New Guinea Broadcasting. So both reasons were true, one, a rational reason, the other, a political reason (why I was sent to Malang).

After I finished my studies at the APDN I was sent back to Papua. For nearly three years I was not given any position. This indeed proved that my being sent away was not only to help but also to impede me. During this time it was as if my government career was obstructed. Actually, in the time of the Dutch, I was promoted faster than my classmates; in fact I far outstripped them, moving from scale 10 to 18. In the Indonesian period I could not stand seeing bad things, and I had to remain silent, I was not supposed to talk. Then I was assigned in Manokwari and eventually, accused of being a member of the OPM. 


\section{EXPERIENCE DURING THE AGT OF FREE CHOICE}

In 1969 I was in Jayapura but was asked to return to Biak, because I had family there, my parents were there. The order was very firm: 'You must carry out my order. Do we have to escort you?' I said there was no use in that. What was important, being informed of the order, was for me to go directly myself.

When the Penentuan Pendapat Rakyat (Pepera, the 'referendum' known in English as the Act of Free Choice) meeting was held I departed from Jayapura. On arriving in Biak I was greeted by the Air Force on the airfield. I was brought to an Air Force custody place. The lieutenant was a very good man, a Javanese Christian, from Solo. He said: 'Little brother, sit here until the meeting there is done, then I'll take you home.'

I asked who had reported me. Then the lieutenant told me: 'It was your father, little brother, who gave the order.' Why had he done that? 'I think your father is wise, rather than having you speak badly later - not all of us army people have human hearts, some would do damage. I met with your father, got the story and I said: 'Done, I'll meet little brother at the airfield.' The Air Force at that time included the armed forces, which were still clean, just like the navy was. After the Act of Free Choice meeting was finished, I was immediately escorted home to Bosnik. My father had gone home ahead. I felt as if my fathers' judgments were good.

What concerned me, is what I call confused politics. One example is that after the OPM uprising happened in Manokwari, the Indonesian government started to bring more troops into Papua. The UN troops, in fact the UN itself, could not do anything more. The Papuan people became confused and frightened. The situation was controlled by the Indonesian government even though supervision was still actually under the UNTEA. Papuan political predictions became chaotic. Any expectations of restrictive action by the UNTEA against the entry of troops from Jakarta vanished.

In this uncertain political situation emerged Papuans who called themselves Papua fighters, in the style of the Greater Indonesia fighters, and acted as informants to the Indonesian army. They were recorded and regarded as freedom fighters, and then selected So those who represented the Papuans were not good people. Maybe there were one or two who were, but the majority of those people had formerly been informants. Or they were people who had been put in prison because 
they had stolen or committed other crimes. When Indonesia came they reported themselves, claimed they had struggled until the Dutch threw them in jail, although in fact the persons concerned were thieves or murderers.

Another impact was the role of the military in the civilian government and the Act of Free Choice. The role of the military in the civilian government increasingly intensified, especially in preparation for the implementation of the New York Agreement. As a concrete example, I will try to paraphrase a secret letter from the commander of the Merauke Military Resort 17, Colonel Blego Sumarto. The letter, no. R-24/1969 regarding Security for the Act of Free Choice, dated 8 May 1969, was addressed to the bupati of Merauke in his capacity as a member of Muspida (the Council of Local Government Officials). The contents of the letter, among other things, stated: In the event that during the polling period it is necessary to replace members of the Consultative Council, replacements should be made well before the Act of Free Choice deliberations. If reasonable excuses for the replacements are not obtained, whereas, on the other hand, it is considered essential for that member to be replaced because he would endanger the victory of the Act of Free Choice, one must dare to employ an unreasonable way to get rid of the member concerned from the session before the commencement of the Consultative Council on the Act of Free Choice. The inference of the letter was: we must absolutely win the Act of Free Choice, whether by reasonable or by unreasonable means. 